\title{
Heat Pump Use in Rural District Heating Networks in Estonia
}

\author{
Kertu LEPIKSAAR ${ }^{1 *}$, Kiur KALME ${ }^{2}$, Andres $\mathrm{SIIRDE}^{3}$, Anna VOLKOVA ${ }^{4}$ \\ 1,3,4 Tallinn University of Technology, Ehitajate tee 5, 19086 Tallinn, Estonia \\ ${ }^{2}$ Elering AS, Kadaka tee 42, 12915 Tallinn, Estonia
}

\begin{abstract}
District heating has proven to be an efficient way of providing space heating and domestic hot water in populated areas. It has also proven to be an excellent way to integrate various renewable energy sources (RES) into the energy system. In Estonia, biomass covers most of the heat demand, but carbonintensive fuels are still used to cover peaks and lows. Heat pumps can be a good solution for rural areas, as there is usually plenty of land available for heat pump facilities. In addition, heat pumps require low-grade heat sources such as ambient air, groundwater, lakes, rivers, sea, sewage water, and industrial waste heat. One of the downsides of heat pumps is the need for large investments compared to boilers fired by natural gas and biomass, and electric boilers. This study examines the impact of heat pump use on consumer prices for district heating in rural district heating networks in Estonia.
\end{abstract}

Keywords - Consumer prices; district heating; heat pumps; low-temperature heat sources; rural areas

\begin{tabular}{|lll|}
\hline Nomenclature & & \\
$A H D$ & annual heat demand & MWh \\
$A P$ & allowable profit & EUR \\
$C C$ & capital costs & EUR \\
$\mathrm{CHP}$ & combined heat and power plant & - \\
$C O P$ & coefficient of performance & - \\
$\mathrm{DH}$ & district heating & - \\
$h l$ & heat loss & $\%$ \\
$\mathrm{HP}$ & heat pump & - \\
$O M$ & operation and maintenance costs & EUR \\
$P r_{\text {max }}$ & maximum heat price & EUR/MWh \\
$\mathrm{RES}$ & renewable energy sources & - \\
$W A C C$ & weighted average cost of capital & EUR \\
$V C$ & variable costs & EUR \\
\hline
\end{tabular}

* Corresponding author.

E-mail address: kertu.lepiksaar@taltech.ee 


\section{INTRODUCTION}

There has been a growing interest in the utilisation of electrical solutions in the heating sector in recent years. The wide range of low-grade heat sources available along with advanced and highly efficient heat pump (HP) technology has generated widespread interest in the use of large-scale heat pumps in district heating systems. District heating (DH) has proven to be an efficient way of providing space heating and domestic hot water in populated areas [1]. It has also proven to be an excellent way to integrate various renewable energy sources (RES) into the energy system [2]-[4]. However, viability and feasibility are often critical issues for rural district heating networks because consumption density tends to be low and consumption often dwindles due to declining rural populations [5], improved energy efficiency in buildings [5], and warming climate conditions [6]-[8].

Recent research on power-to-heat technologies [9] has focused on the effects of wind energy penetration into electricity markets on the optimal power-to-heat capacity in local district heating systems. The effects of power-to-heat technologies on Germany's energy system were explored in [10], and it was discovered that the interaction between the heating and electricity sectors will make both sectors flexible when dealing with short-term fluctuations in wind and solar energy production. When biomass is limited, utilising powerto-heat solutions in systems with an ever-increasing share of renewable energy will also help to incorporate even more RES into the heating sector, according to [10]. A comparison between different methods for the best design of distributed power systems was made in [11], where heat pumps were considered as a power-to-heat solution. A risk assessment for integrated heat and electricity systems was conducted in [12], which determined that the use of power-to-heat solutions (electric boilers and heat pumps) leads to reduced risks when a greater proportion of renewable energy sources is incorporated into the system [13].

As per the European Commission's EU Energy System Integration Strategy, sector coupling will massively boost electricity consumption, increasing generation of renewable energy, and propagating RES technologies [14]. According to [15], heat pumps (as power-to-heat solutions) play a significant part in the coupling of RES and the heating sector, and the amount of heat obtained from RES is highly dependent on the type of strategy; the largest number of RES can be incorporated into a system using a wind energy generation-based strategy. It is mentioned in [16], that when the heating and electricity sectors are interconnected, residential heating load has considerable potential to maximise the utilisation of wind power while minimising carbon emissions.

DH is very important for Estonia [17]. In [18], Estonian DH regions are discussed, and five different scenarios for all types of Estonian DH regions are investigated. In [18], it is concluded that it is necessary to consider all possible changes in the DH network when planning a DH region. Therefore, we propose an algorithm based on 146 Estonian DH networks of different sizes, lengths, capacities and primary energy structures to help predict possible changes in DH networks.

This study was designed to assess the impact of heat pump use in rural DH networks in Estonia on DH consumer prices. Heat pumps can be a good solution for rural areas, as there is usually plenty of land available for heat pump facilities. In addition, heat pumps require low-grade heat sources such as ambient air, groundwater, lakes, rivers, sea, sewage water, and industrial waste heat [19], [20]. One of the downsides of heat pumps is the need for large investments compared to boilers fired by natural gas and biomass, and electric boilers [21].

First and foremost, various aspects must be taken into account when considering the possibilities of using heat pumps in $\mathrm{DH}$ networks. In order to maintain balance in the electricity grid, it is important to assess how the addition of a large number of electricity 
consumers, such as heat pumps, would affect the balance and the electricity market. Electricity market options for heat pumps in rural DH networks are described in [22] for the integration of heat pumps into rural DH networks in Austria. Since heat pumps can play an important role in balancing the electricity market, [22] shows how heat pumps can be used as regulators in the electricity market.

Oil shale is the primary energy source in Estonia, as well as an essential source of fuel and the major component in the energy mix. On the one hand, using oil shale as the main source of fuel guarantees a significant degree of energy security. However, it is an extremely carbonintensive fuel. Consequently, the production of energy from oil shale results in a significant amount of greenhouse gases that affect the climate. Because of this, the Estonian economy has twice the amount of carbon dioxide $\left(\mathrm{CO}_{2}\right)$ than is usual in the EU. This is rapidly changing as the Estonian government continues to dismantle old energy plants and the number of innovations aimed at reducing $\mathrm{CO}_{2}$ emissions and their negative impact is increasing. The amount of power generated in Estonia is more than its consumption, so the state trades electricity.

The total power generated in Estonia in 2019 was 7.615 TWh, while the demand for it was 8.257 TWh. In 2020, the amounts were 4.398 TWh and 7.954 TWh, respectively. More than half of the electricity was generated using oil shale (56\%), as well as biomass $(17 \%)$, wind $(9 \%)$, and sustainable waste (1\%) power plants. Latvia (76\%) and Finland (24\%) received 2.704 TWh of the electricity generated [23].

All three Baltic states are attempting to separate from the Russian power grid and join the Western European grid, which is due to be completed by 2025. Another important goal climate neutrality - must be achieved by 2050 . To achieve this goal, the Baltic countries must increase their renewable energy source (RES) capacities [23].

The largest RES in Estonia is the $48 \mathrm{MW}$ wind power plant in Aulepa, the largest of its kind in the Baltics. Wind power plants (303 MW in total) are located inland in the north-east, north-west and west of Estonia. There are currently no offshore wind parks in Estonia. The largest combined heat and power plants (CHP) are Tartu CHP and Tallinn CHP with a capacity of $25 \mathrm{MW}$ each. Biofuel plants are CHPs and therefore have to be spread throughout Estonia, close to urban settlements that use heat. It is known that $102 \mathrm{MW}$ of biomass-powered, $17 \mathrm{MW}$ of waste-powered, and $11 \mathrm{MW}$ of biogas-powered plants are connected to the network [24].

There are three small DH systems in Estonia that use HPs as innovative heat generation technologies. They are located in Palamuse, Kaarepere, and Kiikla. Palamuse has two small, isolated DH systems where the demand for heat is supplied by ground source HPs. The DH network consists of the Palamuse School and its auxiliary buildings. The other network supplies DH to private structures (7 buildings). These HPs were commissioned in 2013. The annual DH consumption of the Palamuse School is $830 \mathrm{MWh}$ and the private building network's annual consumption is $750 \mathrm{MWh}$. The annual COP of the HPs averages 2.6 [25]. Similarly, HPs are used in the DH network in Kaarepere, near Palamuse. As in the previous case, Kaarepere also uses ground source HPs. The consumers of the network are 6 private buildings and a kindergarten. Their annual heat consumption is $730 \mathrm{MWh}$. The annual COP of the pumps is usually 2.3. HPs were introduced in 2013, same as in Palamuse [25]. The heat demand is covered by a $400 \mathrm{Kw} \mathrm{HP}$ in the DH network of Kiikla village. It uses water from a nearby mine as a heat source. The HP was introduced in 2012, and according to its manufacturer, its $C O P$ should be 4.1 (on average). The annual heat consumption of the Kiikla DH network is $530 \mathrm{MWh}[26]$. 
Three seawater HPs are used for heating and cooling of the Seaplane Harbour historic centre in Tallinn. The introduced heating capacity of the facility is $395 \mathrm{~kW}$, the cooling capacity is $250 \mathrm{~kW}$, and the power capacity is $180 \mathrm{~kW}$ [27].

The use of heat pumps in DH also has a positive effect on air quality since heat pumps do not require combustion to generate heat and therefore no fine particles or acid-oxides $\left(\mathrm{NO}_{\mathrm{x}}\right.$ and $\mathrm{SO}_{\mathrm{x}}$ ) are emitted. Biomass boilers are widely used because they are considered $\mathrm{CO}_{2}$-neutral and because biomass is widely available in Estonia. However, the downside to using biomass is that it can be a source of air pollution. The impact of biomass boilers on the atmosphere has been studied in [27]-[29]. Emissions from biomass boilers depend on combustion methods. It is stated in [30], that $\mathrm{NO}_{\mathrm{x}}$ and $\mathrm{SO}_{\mathrm{x}}$ emissions are lower than the environmentally harmful amounts, and $\mathrm{CO}_{2}$ emissions do not exceed the amount consumed by plant growth. This makes biomass an environmentally friendly fuel. On the other hand, it was found in [28] that fine particle emissions from biomass combustion can be harmful to health if flue gas cleaning equipment is not used.

When considering HPs as a source for space heating, it should be borne in mind that the use of heat pumps to generate heat instead of combustion boilers has an overall positive effect on the atmosphere only if the electricity used for HPs is also produced in accordance with the clean production principles and from renewable energy sources. Fine particle and acid oxide emissions in the event of combustion can be reduced by using air treatment equipment such as flue gas condensers, electric precipitators and various kinds of filters. Such equipment can be expensive and not all boiler houses have it installed. According to Directive 2015/2193 of the European Parliament and of the Council of 25 November 2015 on the limitation of emissions of certain pollutants into the air from medium combustion plants, the maximum amount of fine particles (dust, fly ash) for medium-sized biomass boilers is $20 \mathrm{mg} / \mathrm{Nm}^{3}$ [31]. Emissions of fine particles are also regulated by Directive 2016/2284 of the European Parliament and of the Council of 14 December 2016 on the reduction of national emissions of certain air pollutants, which established an emission reduction strategy [32].

There are about 230 district heating networks in Estonia, and $95 \%$ of them use woodchips as their primary fuel, while shale oil or natural gas is used to cover peak loads. In other DH networks, the main fuel is natural gas or shale oil. Most biomass boilers were installed after 2014 with the support of the European Cohesion Fund [33]. As the European Union's goal is to become climate neutral by 2050 [34], all fossil fuel-fired boilers must be replaced with RES, which means that it is necessary to find a sustainable solution to cover peak loads. Replacing old biomass boilers with HPs is a solution that should be discussed.

Price is the most important factor for consumers. The Estonian DH market is regulated by the District Heating Act and the Competition Act, and the Competition Authority approves the maximum prices charged in the network regions. At the beginning of 2020, the weighted average of the maximum DH prices was EUR 60/MWh; the lowest price was EUR 35/MWh (excluding VAT $20 \%$ ) and the highest price was EUR 86/MWh [35]. Typically, the actual selling price is very close to the maximum price indicated. In rural areas, where heat demand density is usually quite low, the costs of boiler house and network operations and maintenance are relatively high. This results in a high $\mathrm{DH}$ consumer price. When $\mathrm{DH}$ is produced using heat pumps, the price of heat is directly related to the price of electricity. This study provides a thorough analysis of how the use of HPs in rural DH networks will affect the consumer price of $\mathrm{DH}$ and, as a result, it will determine the areas where the use of HPs for DH can be cost-effective and have a positive impact on the DH consumer price. At the same time, suitable HP capacities are estimated for DH networks of different sizes, resulting in two types of solutions: those that use HPs for covering only peaks and troughs and fully HP-based solutions. 


\section{METHODOLOGY}

Since this study is focused on rural areas, only DH networks with an annual consumption of less than $16 \mathrm{GWh}$ are considered. There are about $140 \mathrm{DH}$ networks in Estonia that meet this criterion. This limit was chosen because all DH regions with an annual heat consumption below it can be considered a rural area in Estonia. The average population in these areas is anywhere from 165 to 5000 residents, and the number of DH consumers ranges from 3 to 70 . In this study, all these networks are divided into seven groups according to annual consumption. The criterion for division was to maintain minimum fluctuations in annual heat consumption within a group. It was significant to include all groups, but special focus was on small district heating networks, because heat pump integration is especially important in the case of small DH networks. That is why there are 3 groups for district heating networks below $5000 \mathrm{MWh}$. The main characteristics of these groups are presented in Table 1. Annual consumption figures are given for a 'normalised' year. The input data in Table 1 are taken from the heat management and development plans of the DH networks considered. In most cases, DH is also used for domestic hot water.

TABLE 1. MAIN CHARACTERISTICS OF DH GROUPS

\begin{tabular}{llllll}
\hline $\begin{array}{l}\text { Group } \\
\text { no. }\end{array}$ & $\begin{array}{l}\text { Average annual } \\
\text { heat consumption, } \\
\text { MWh/year }\end{array}$ & $\begin{array}{l}\text { Average number } \\
\text { of consumers in } \\
\text { the DH network }\end{array}$ & $\begin{array}{l}\text { Average DH } \\
\text { price, } \\
\text { EUR/MWh }\end{array}$ & $\begin{array}{l}\text { Average DH } \\
\text { supply } \\
\text { temperature, }{ }^{\circ} \mathbf{C}\end{array}$ & $\begin{array}{l}\text { Number of such } \\
\text { DH networks in } \\
\text { Estonia }\end{array}$ \\
\hline 1 & 681 & 3 & 70.3 & 80 & 23 \\
2 & 1914 & 6 & 67.4 & 80 & 58 \\
3 & 3956 & 15 & 64.5 & 80 & 24 \\
4 & 6235 & 25 & 61.7 & 85 & 8 \\
5 & 7812 & 37 & 56.7 & 90 & 8 \\
6 & 10393 & 52 & 64.4 & 100 & 9 \\
7 & 14192 & 70 & 57.1 & 110 & 5 \\
\hline
\end{tabular}

For all network groups, annual heat demand profiles have been generated using EnergyPro software, based on the annual heat demand, DH network temperatures and ambient temperatures. Base and peak loads that are important for estimating the required HP thermal capacity were determined using the generated heat demand profiles. Since the average ambient temperature for continental Estonia has been chosen (islands are excluded due to the milder climate), the shape of the heat demand profile is thus the same for all groups, and the groups with higher annual consumption lead to higher base and peak loads. Heat demand profiles for all groups are shown in Fig. 1.

Depending on the heat demand profile, different options were proposed for each group. This study presents two different options. The first option is to use a biomass boiler for base load and HP for summer loads and partly during the heating season. The criterion for selecting the base load boiler is to obtain the maximum amount of heat from the base load boiler. It is also assumed that the minimum load for the boiler is $50 \%$ of its nominal capacity and the maximum load is $110 \%$ of its nominal capacity. The second option is that all demand is covered by HPs.

When selecting HPs, it is important to know which heat sources are located nearby, as the temperature level of the heat source determines the coefficient of performance $(C O P)$ of the HP. 


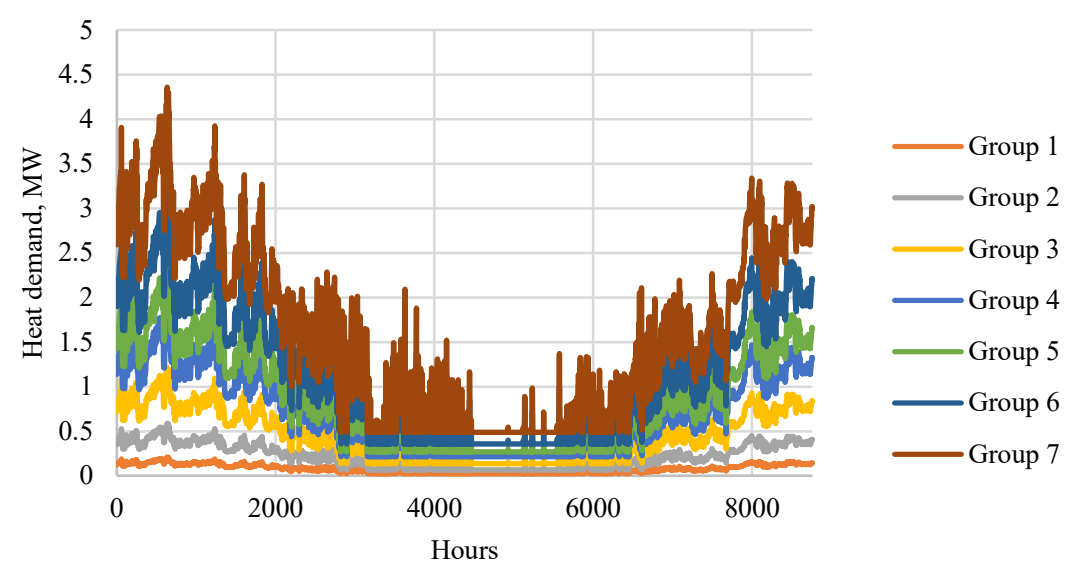

Fig. 1. Heat demand profiles for each group.

In this study, the COP for each possible heat source is estimated considering the temperature levels of possible local low-temperature heat sources and the temperature levels in rural DH networks. Possible heat sources discussed in this study are ground, seawater, lakes and rivers, and sewage water. This study obtained the necessary heat source temperatures for every hour using data from the Estonian National Weather Service [36]. For sewage water, the data given in [20] are used.

To estimate the COP of HPs, the Carnot equation for heat pump efficiency was used (Eq. (1)) with efficiency coefficient $\varepsilon=1$ :

$$
C O P=\varepsilon \frac{T_{\text {supply }}}{T_{\text {supply }}-T_{\text {source }}},
$$

where $T_{\text {supply }}(\mathrm{K})$ is the DH supply temperature and $T_{\text {source }}(\mathrm{K})$ is the heat source temperature.

The average $C O P$ s of all mentioned HP heat sources for each hour, considering heat source temperatures, are shown in Fig. 2. COP estimation also takes the DH supply temperature for each group into account.

To estimate the necessary electric capacity of HPs for each group for both options, the minimum $C O P$ value is used. This ensures the necessary electric capacity under all conditions. The higher the ambient temperature, the higher the $C O P$.

The required electric capacities for option 1 (HP and biomass boiler) and option 2 (HP only) for each group and for different heat sources are shown in Table 2.

The proposed options and the existing solution are compared by the DH consumer price calculated using the Estonian Competition Authority's Method for DH maximum price [37]. In order to calculate the prices, the required investments, annual fuel costs, and operations and maintenance costs were estimated. 


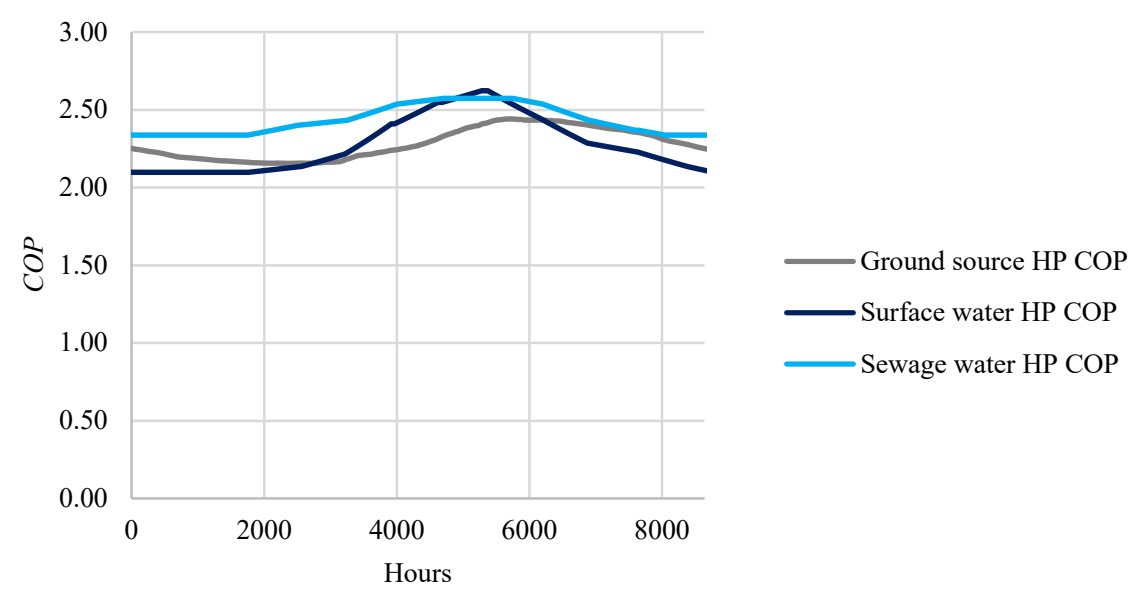

Fig. 2. Average $C O P$ for ground source, hydrothermal and sewage water HPs.

TABLE 2. HP ELECTRIC CAPACITIES FOR BOTH OPTIONS

\begin{tabular}{lllllll}
\hline \multirow{2}{*}{$\begin{array}{l}\text { Group } \\
\text { no. }\end{array}$} & \multicolumn{2}{l}{ Option 1 - HP electric capacity, $\mathbf{M W}_{\text {el }}$} & \multicolumn{3}{l}{ Option 2 - HP electric capacity, $\mathbf{M W}_{\text {el }}$} \\
\cline { 2 - 7 } & $\begin{array}{l}\text { Ground } \\
\text { source }\end{array}$ & $\begin{array}{l}\text { Surface } \\
\text { water }\end{array}$ & $\begin{array}{l}\text { Sewage } \\
\text { water }\end{array}$ & $\begin{array}{l}\text { Ground } \\
\text { source }\end{array}$ & $\begin{array}{l}\text { Surface } \\
\text { water }\end{array}$ & $\begin{array}{l}\text { Sewage } \\
\text { water }\end{array}$ \\
\hline 1 & 0.033 & 0.033 & 0.031 & 0.088 & 0.093 & 0.084 \\
2 & 0.081 & 0.085 & 0.077 & 0.247 & 0.26 & 0.234 \\
3 & 0.164 & 0.164 & 0.155 & 0.509 & 0.509 & 0.482 \\
4 & 0.273 & 0.287 & 0.259 & 0.845 & 0.888 & 0.803 \\
5 & 0.357 & 0.375 & 0.319 & 1.11 & 1.164 & 0.992 \\
6 & 0.511 & 0.534 & 0.490 & 1.608 & 1.608 & 1.541 \\
7 & 0.755 & 0.784 & 0.726 & 2.366 & 2.459 & 2.277 \\
\hline
\end{tabular}

According to the Estonian Competition Authority's heat price calculation method, the maximum heat price depends on the allowable profit and sales capacity since the annual sales capacity of a heat producer is equal to the annual heat demand plus heat losses. The method of the Estonian Competition Authority has also set a limit for the allowable heat loss, which is $15 \%$. The maximum heat price $P r_{\max }$ (EUR/MWh) according to the method of the Estonian Competition Authority can be calculated using Eq. (2):

$$
P r_{\max }=\frac{A P}{A H D \cdot(1+h l)},
$$

where $A P$ (EUR) is the allowable profit, $A H D(\mathrm{MWh})$ is the annual heat demand and $h l(\%)$ is the heat loss. Allowable profit consists of several other components: variable costs, operating costs, capital costs, and weighted average cost of capital (WACC). The WACC is determined by the Estonian Competition Authority and for heat producers the WACC is $5.76 \%$. To determine the possible heat price for both proposed solutions, it is necessary to estimate the variable costs, operating costs and capital costs, since the allowable profit is calculated as follows: (Eq. (3)). 


$$
A P=V C+O M+C C+W A C C
$$

Variable costs $V C$ (EUR) consist of fuel costs (both biomass and electricity), environmental fees and water and sewerage services. For an annual estimate of variable costs, biomass and electricity prices are needed. The 2020 NordPool prices for Estonia are used for both electricity and biomass prices. The biomass price has been quite stable in recent years and in 2020 the price was EUR 16.42/MWh, which was also used in this study. Since biomass combustion emits fine particles, all biomass boiler houses must also pay environmental fees for fine particle emissions. The fine particle emission fee for particles smaller than $2.5 \mu \mathrm{m}$ is EUR 1000/t [38]. In the case of this study, it is assumed that flue gas treatment equipment is not used, because flue gas condensers are usually installed in bigger boiler houses with a base load of $7 \mathrm{MW}$ and more. This is mainly due to the fact that investments in this type of equipment are quite high and it is more economical for smaller boiler houses to pay environmental fees for particle emissions than to install flue gas condensers.

Water and sewerage services are also considered variable costs. Water and sewerage services are necessary for $\mathrm{DH}$ as water preparation and water use from local water utilities is necessary. The cost of water and sewerage services is not related to the heat source and depend only on the heat demand. Based on information from various regional heat management development plans in Estonia, the cost of the service is approximately EUR 17.8/MWh. This provides the same result for both options.

Operations costs $O M$ (EUR) are the costs for boiler and HP services that must also be considered. Capital costs $C C$ (EUR) are the investments divided by the expected technical useful life of the equipment. It is expected that service life for both biomass boilers [39] and HPs [40] is 20 years. The operations and maintenance $(O M)$ costs for a biomass boiler are assumed to be EUR 9.5/MWh, according to the data given in several Estonian regional heat management development plans. To estimate the costs of HP operation and maintenance, the data from [41] were used (EUR 14/kWh). The value is the same for ground source, surface water and sewage HPs.

The main assumptions used in this study are listed below:

- The base load boiler was selected based on the maximum number of hours of use at full load;

- HP COP was estimated using the Carnot equation for HP efficiency;

- To estimate HP COP, the annual heat source temperature graphs and DH supply temperature were used;

- The minimum COP value was used for the required HP electric capacity;

- For DH consumer prices, the Estonian Competition Authorities Method was used;

- To estimate fuel costs, 2020 prices (electricity and woodchips) were used;

- Flue gas treatment equipment was not considered;

- Water and sewerage services are the same for both options.

\section{Results}

Estimates of DH heat source capacity based on the heat demand profiles and previously described assumptions are shown in Fig. 3. 


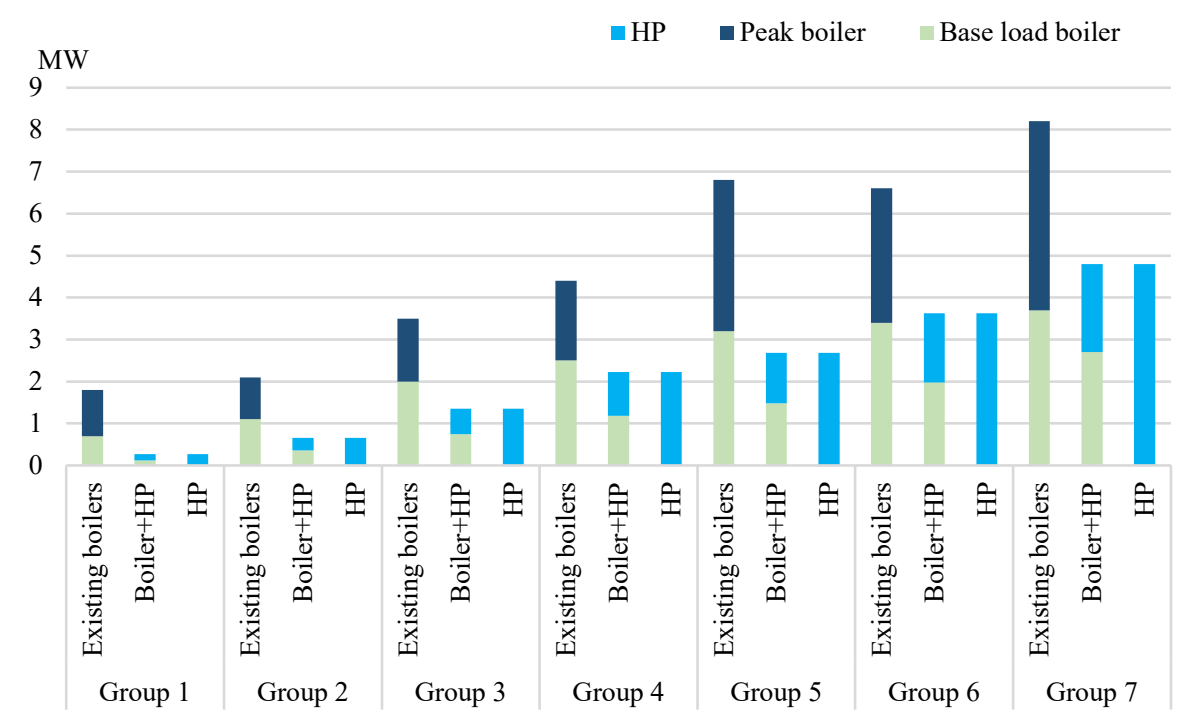

Fig. 3. Existing boiler capacities and capacity estimates for each group.

The results also showed that the maximum share of the total heat that can be delivered by base load boilers is $78 \%$, and peak boilers or HPs can cover the rest, i.e., $22 \%$. In addition, the existing base load boiler capacities are significantly higher than those proposed in this study. For smaller DH networks (groups 1, 2 and 3), this may be associated with high losses in the network caused by the low heat demand density.

Since HPs are also electricity consumers, when they are used for heat production in $\mathrm{DH}$, they can significantly increase the demand for electricity in the power grid. Therefore, it is necessary to estimate the annual HP power consumption to determine the total extra power consumption that is caused by DH HPs.

The total number of electricity consumers to be added to the electricity grid for both options is shown in Table 3.

TABLE 3. AdDITIONAL ELECTRICITY CONSUMERS FOR BOTH OPTIONS

\begin{tabular}{lllllll}
\hline \multirow{2}{*}{$\begin{array}{l}\text { Group } \\
\text { no. }\end{array}$} & \multicolumn{2}{l}{ Option 1 - HP electric capacity, $\mathbf{M W}_{\mathrm{el}}$} & \multicolumn{3}{l}{ Option 2 - HP electric capacity, $\mathbf{M W}_{\mathrm{el}}$} \\
\cline { 2 - 6 } & $\begin{array}{l}\text { Ground } \\
\text { source }\end{array}$ & $\begin{array}{l}\text { Surface } \\
\text { water }\end{array}$ & $\begin{array}{l}\text { Sewage } \\
\text { water }\end{array}$ & $\begin{array}{l}\text { Ground } \\
\text { source }\end{array}$ & $\begin{array}{l}\text { Surface } \\
\text { water }\end{array}$ & $\begin{array}{l}\text { Sewage } \\
\text { water }\end{array}$ \\
\hline 1 & 0.76 & 0.76 & 0.71 & 2.02 & 2.14 & 1.93 \\
2 & 1.86 & 1.96 & 1.77 & 5.68 & 5.98 & 5.38 \\
3 & 3.77 & 3.77 & 3.57 & 11.71 & 11.71 & 11.09 \\
4 & 6.28 & 6.60 & 5.96 & 19.44 & 20.42 & 18.50 \\
5 & 8.21 & 8.63 & 7.34 & 25.53 & 26.77 & 22.82 \\
6 & 11.75 & 12.28 & 11.27 & 36.98 & 36.98 & 35.44 \\
7 & 17.37 & 18.03 & 16.70 & 54.42 & 56.56 & 52.37 \\
Total & 50.00 & 52.03 & 47.31 & 155.78 & 160.56 & 147.50 \\
\hline
\end{tabular}

Table 3 shows that applying Option 1 to all rural DH networks will result in an additional consumption of around $50 \mathrm{MW}$ in the electric grid. If all considered rural DH networks choose 
to cover the heat demand using HPs, the additional consumption will amount to $160 \mathrm{MW}$. The peak consumption in the Estonian electric grid is usually around 1500-1600 MW, therefore, the consumption of HPs in rural areas will amount to a maximum of about $10 \%$ extra consumption.

Annual electricity consumption is also necessary to estimate annual fuel costs since electricity is considered a fuel for HPs.

Fig. 4 shows the annual fuel costs for Option 1 and Option 2 in the case of ground source, surface water and sewage water HPs.

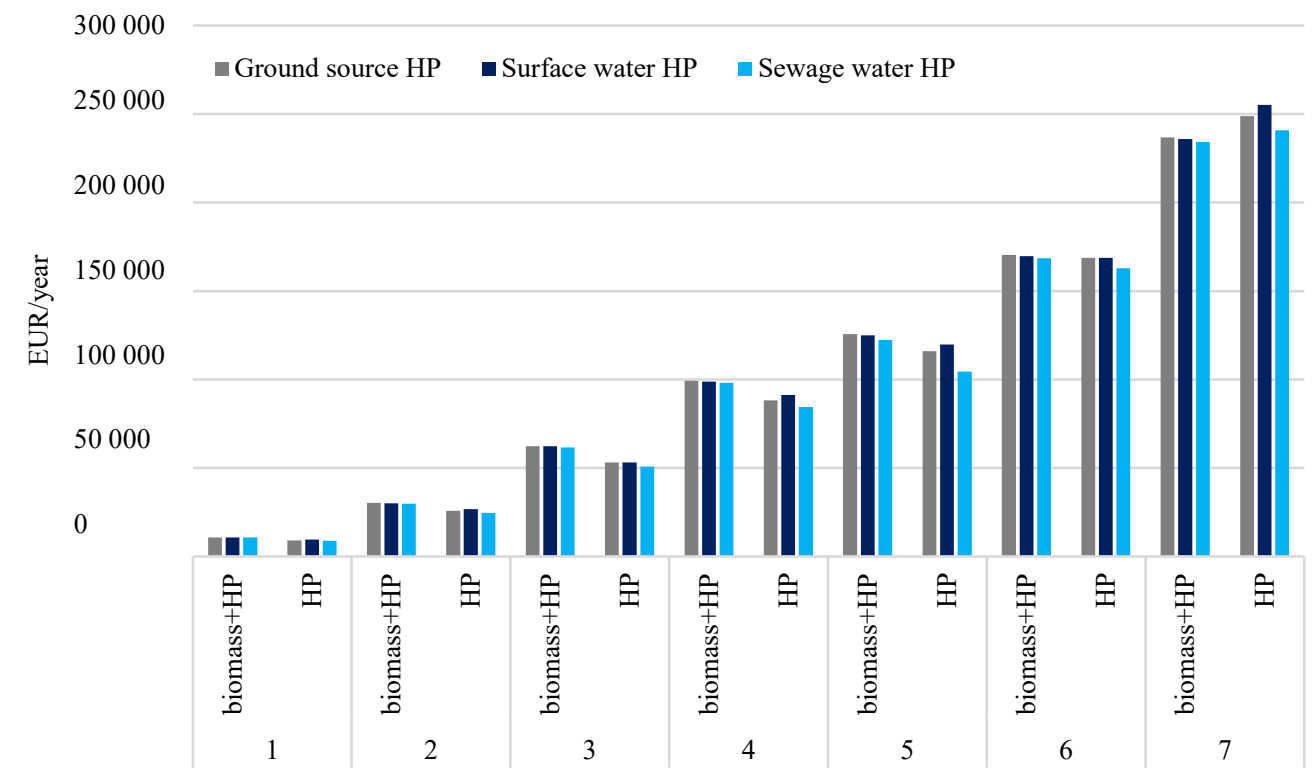

Fig. 4. Annual fuel costs for each option.

TABle 1. AnNual Particle EMissions And ENVIRONMENTAL FEES For Option 1

\begin{tabular}{lll}
\hline Group no. & $\begin{array}{l}\text { Particle emissions for Option } 1 \\
\text { biomass boiler, t/year }\end{array}$ & $\begin{array}{l}\text { Annual fee for fine particle } \\
\text { emissions, EUR/year }\end{array}$ \\
\hline 1 & 0.350 & 350 \\
2 & 0.977 & 977 \\
3 & 2.013 & 2013 \\
4 & 3.174 & 3174 \\
5 & 3.976 & 3976 \\
6 & 5.282 & 5282 \\
7 & 7.216 & 7216 \\
\hline
\end{tabular}

It can be seen that sewage water HPs have slightly lower annual fuel costs than other types of HPs, which can be explained by higher heat source temperatures. It can be also seen that the option where only HPs are used as the DH heat source has lower fuel costs, which can be explained by the fact that the average electricity price is lower than the price of woodchips. 
Table 4 shows the average annual amount of emitted fine particles for each group and the corresponding fee that can be accounted for as part of the variable costs.

The results in Table 4 show that in any case, the environmental fees for fine particle emissions are not significant compared to other variable costs. Still, the results in Table 4 show how much fine particles would not be emitted when HPs are used instead of biomass boilers.

Operations and maintenance costs $(O M)$ for both options are given in Table 5.

TABLE 5. ANNUAL OPERATIONS AND MAINTENANCE COSTS FOR BOTH OPTIONS

\begin{tabular}{lll}
\hline $\begin{array}{l}\text { Group } \\
\text { no. }\end{array}$ & $\begin{array}{l}\text { Total annual operations and } \\
\text { maintenance costs for Option 1, } \\
\text { EUR/year }\end{array}$ & $\begin{array}{l}\text { Total annual operations and maintenance } \\
\text { costs for Option 2, EUR/year }\end{array}$ \\
\hline 1 & 8574 & 3780 \\
2 & 22387 & 9240 \\
3 & 45987 & 18900 \\
4 & 73932 & 31220 \\
5 & 91014 & 37520 \\
6 & 121829 & 50820 \\
7 & 164226 & 67200 \\
\hline
\end{tabular}

It can be seen in Table 5 that the $O M$ costs are reduced by more than half in the case of Option 2, where only HPs are used. This is because Option 1 also includes two different types of heat sources that require maintenance, while Option 2 only requires one type of maintenance service. Option 1 has lower HP $O M$ service costs, but there are additional $O M$ costs for the biomass boiler, making the final $O M$ cost higher than that of Option 2.

The necessary investments for each group in Option 1 (heat pump and biomass boiler) and Option 2 (HP only) are shown in Fig. 5. Information on average biomass boiler investments was obtained from public announcements of the Estonian Environmental Investments Centre [42]. For HP investments, the data from [43] were used.

The actual investment requirements depend on whether the existing base load boiler is new or needs to be replaced. If a new biomass boiler has been installed within the past 10 years, then it should not be replaced and probably only investment in a peak load boiler will be required. If the existing boiler is old or uses carbon-intensive fuels, larger investments are necessary to achieve climate policy goals.

Capital costs $(C C)$ are estimated using investment data provided in Fig. 5 and previously stated technical lifetimes. Once all costs have been estimated, the WACC can be calculated and added to the costs. The final consumer price can be calculated using Eq. (2); it is shown divided by costs in Fig. 6. Fig. 6 shows the final $\mathrm{DH}$ consumer price for both solutions for average HP costs and for the existing DH consumer price.

Fig. 6 illustrates well that the DH consumer price can be reduced by using HPs as a heat source in rural DH networks, since for all DH groups except group 1, the estimated consumer price is lower than the existing DH price. It should also be noted that the existing price has already been reduced through investment support in many cases, but the calculated data in Fig. 6 does not include investment support, which means that the DH consumer price could be even lower. For group 1, the higher calculated price can be attributed to very low annual heat consumption, which results in lower annual profit, making the estimated consumer price higher. 


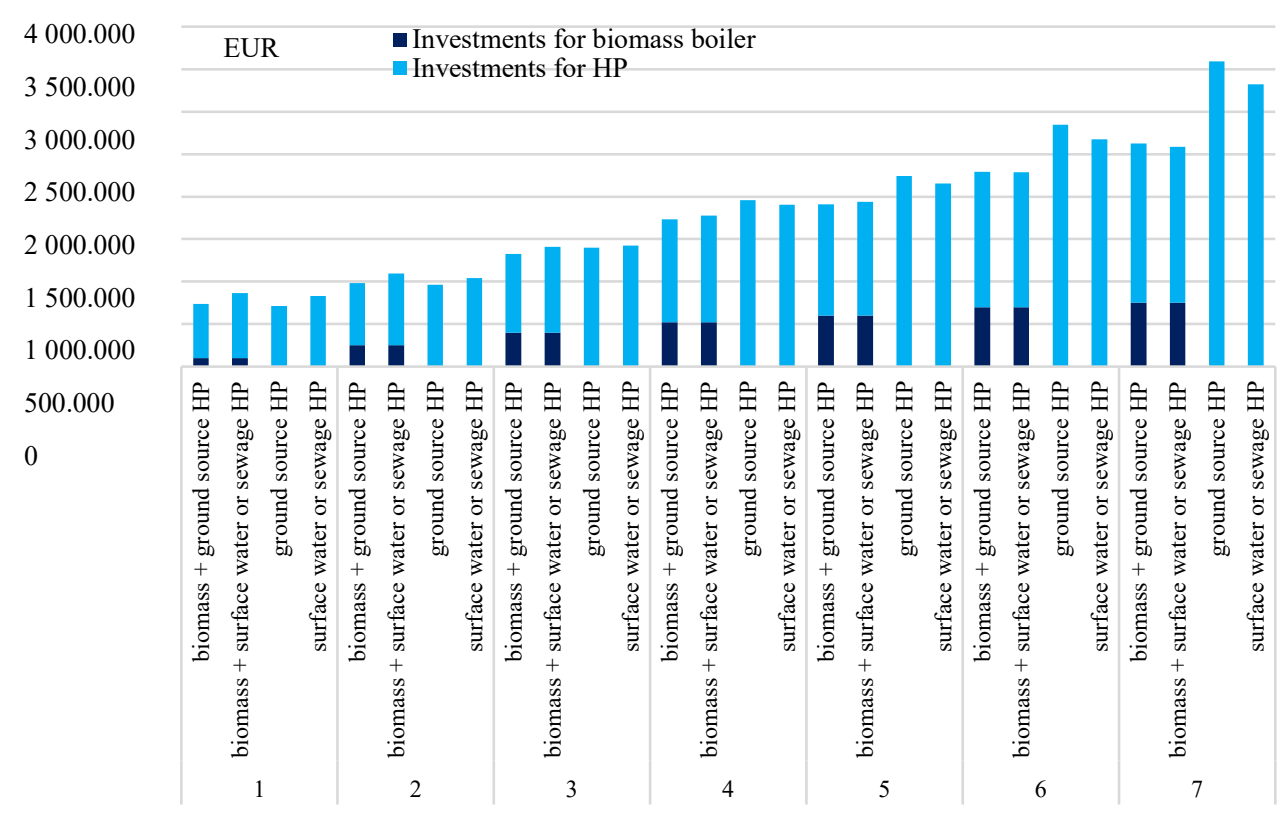

Fig. 5. Required investments for each group for both options.

Fig. 6 also shows that, in all cases, Option 2 results in a lower consumer price than Option 1, the main reason for this is the higher $O M$ costs in the case of Option 1.

There is also a remarkable relationship between annual consumption and annual DH network consumption, indicating a major problem for small rural DH networks. Since there are very few consumers in the network, the annual heat consumption is also very low, resulting in a small profit from heat sales. The relationship is also evident in this study and is presented in Fig. 7, which shows the relationship between annual heat consumption and the estimated consumer price of $\mathrm{DH}$.

Fig. 7 illustrates this relationship well: the higher the annual heat consumption, the smaller the consumer price. However, it can be seen that the consumer price increases exponentially when heat consumption decreases. This leads to the conclusion that for very small DH networks such as groups 1 and 2, finding new consumers for the DH network is crucial to maintaining the viability and feasibility of the DH network.

DH consumer prices for both options for different HP types are also provided in Table 6. 
120

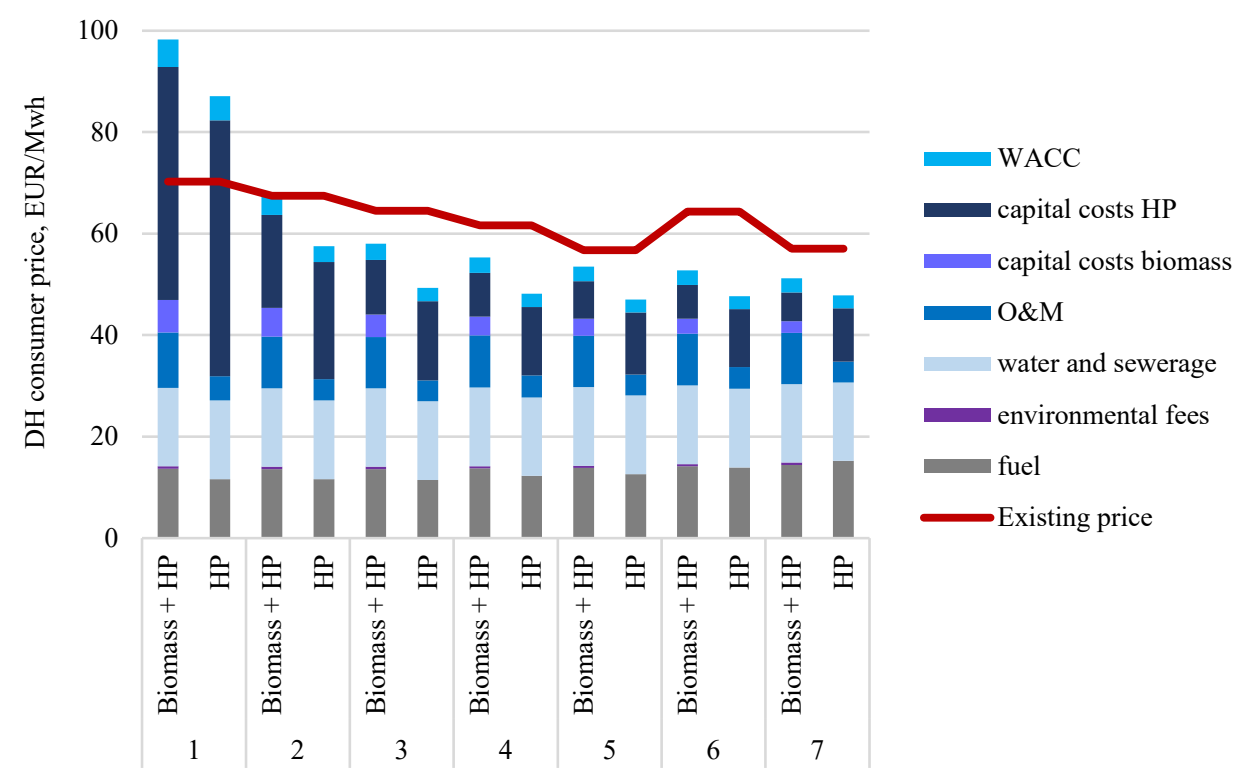

Fig. 6. DH consumer price divided by costs for both solutions and existing consumer price.

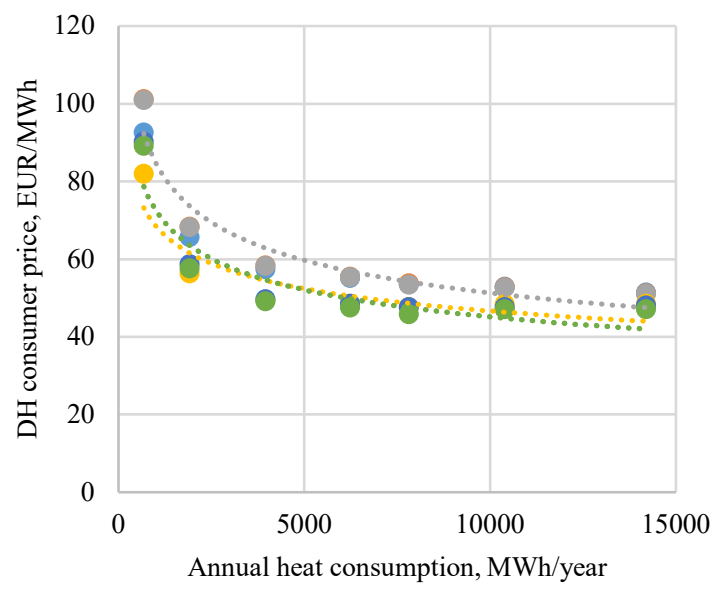

- Biomass + ground source HP

- Biomass + surface water HP

- Biomass + sewage water HP

- Ground source HP

- Surface water HP

- Sewage water HP

Power (Biomass + sewage water HP)

Fig. 7. DH consumer price relationship to $\mathrm{DH}$ annual heat consumption. 
TABLE 2. DH CONSUMER PRICES FOR BOTH SOLUTIONS FOR DIFFERENT TYPES OF HEAT SOURCES

\begin{tabular}{lllllll}
\hline \multirow{2}{*}{$\begin{array}{l}\text { noup } \\
\text { no. }\end{array}$} & \multicolumn{2}{l}{ Consumer price for Option 1, EUR/MWh } & \multicolumn{3}{l}{ Consumer price for Option 2, EUR/MWh } \\
\cline { 2 - 7 } & $\begin{array}{l}\text { Ground } \\
\text { source HP }\end{array}$ & $\begin{array}{l}\text { Surface water } \\
\text { HP }\end{array}$ & $\begin{array}{l}\text { Sewage water } \\
\text { HP }\end{array}$ & $\begin{array}{l}\text { Ground } \\
\text { source HP }\end{array}$ & $\begin{array}{l}\text { Surface water } \\
\text { HP }\end{array}$ & $\begin{array}{l}\text { Sewage } \\
\text { water HP }\end{array}$ \\
\hline 1 & 92.61 & 101.14 & 100.97 & 81.90 & 90.15 & 89.15 \\
2 & 65.66 & 68.32 & 68.20 & 56.25 & 58.64 & 57.64 \\
3 & 57.38 & 58.38 & 58.21 & 49.38 & 49.62 & 49.07 \\
4 & 55.14 & 55.42 & 55.31 & 48.43 & 48.48 & 47.50 \\
5 & 53.55 & 53.69 & 53.39 & 47.66 & 47.57 & 45.76 \\
6 & 52.83 & 52.75 & 52.64 & 48.38 & 47.63 & 47.11 \\
7 & 51.34 & 51.14 & 51.04 & 48.47 & 48.02 & 47.10 \\
\hline
\end{tabular}

Investment costs can be significantly reduced through investment support. According to national plans, new renewable heating solutions are going to be installed, including heat pumps with a capacity of more than $20 \mathrm{MW}$ [44]. When support mechanisms are used, this can reduce the capital costs by $50 \%$ and lead to lower DH consumer prices. DH consumer prices with $50 \%$ investment support are given in Table 7 .

TABLE 3. DH CONSUMER PRICES WiTH 50 \% INVESTMENT SUPPORT

\begin{tabular}{lllllll}
\hline $\begin{array}{l}\text { Group } \\
\text { no. }\end{array}$ & \multicolumn{2}{l}{$\begin{array}{l}\text { Consumer price with 50 \% investment support } \\
\text { for Option 1, EUR/MWh }\end{array}$} & \multicolumn{3}{l}{$\begin{array}{l}\text { Consumer price with 50 \% investment } \\
\text { support for Option 2, EUR/MWh }\end{array}$} \\
\cline { 2 - 7 } & $\begin{array}{l}\text { Ground } \\
\text { source HP }\end{array}$ & $\begin{array}{l}\text { Surface water } \\
\text { HP }\end{array}$ & $\begin{array}{l}\text { Sewage water } \\
\text { HP }\end{array}$ & $\begin{array}{l}\text { Ground } \\
\text { source HP }\end{array}$ & $\begin{array}{l}\text { Surface water } \\
\text { HP }\end{array}$ & $\begin{array}{l}\text { Sewage } \\
\text { water HP }\end{array}$ \\
\hline 1 & 67.77 & 72.04 & 71.87 & 57.85 & 62.20 & 61.20 \\
2 & 53.87 & 55.16 & 55.05 & 44.70 & 46.11 & 45.11 \\
3 & 49.69 & 50.19 & 50.01 & 41.24 & 41.36 & 40.81 \\
4 & 48.76 & 48.87 & 48.75 & 41.20 & 41.45 & 40.47 \\
5 & 47.94 & 47.98 & 47.68 & 41.05 & 41.23 & 39.42 \\
6 & 47.76 & 47.69 & 47.58 & 42.09 & 41.71 & 41.19 \\
7 & 47.08 & 46.96 & 46.85 & 42.66 & 42.64 & 41.72 \\
\hline
\end{tabular}

Comparison of the results in Tables 6 and 7 shows that investment support has a greater impact on consumer prices in smaller DH networks (groups 1, 2 and 3). Through investment support, consumer prices can be reduced by up to $31 \%$ (group 1, sewage HP); the reduction is the smallest in group 7 for Option 1 at only $8 \%$. With investment support, consumer prices will be lower than the existing $\mathrm{DH}$ prices in every single case.

\section{DisCuSSION AND CONCLUSIONS}

The main purpose of this study is to find solutions that will make DH feasible and lower consumer prices for rural DH networks in Estonia. In this study, two different options were considered and compared in terms of the estimated consumer price: biomass boiler plus HP and HP only. Various types of HPs were considered in order to determine which type of heat source is most feasible.

The results show that for smaller DH networks (groups 1, 2 and 3), ground source HPs will be more cost effective than hydrothermal HPs or sewage water HPs. For larger DH networks 
(groups 4, 5, 6 and 7), the difference between HP types is not very significant. In any case, from a consumer price point of view, using HPs to cover total demand is the best solution. However, this is only applicable if existing boilers need to be replaced. DH consumer prices are lower for all heat sources when the total demand is covered by HPs. The average difference between the consumer price of Options 1 and 2 is $13 \%$, the difference is more significant for smaller DH networks (groups 1-5) and less for larger DH networks (groups 6 and 7).

The impact on power consumption was also assessed, leading to the fact that even when all rural DH networks use HPs as heat sources, power consumption in the Estonian electricity grid will increase by about $10 \%(160 \mathrm{MW})$ in case of peak consumption.

The results also show the importance of investment support, which can significantly reduce the consumer price. For smaller DH networks the investment support can reduce the consumer price by up to $31 \%$, while for larger DH networks the effects of investment support are not so noticeable.

The situation for very small DH networks (groups 1,2 and 3) is difficult anyway, as heat demand density is very low and DH is often not viable. One possible solution for these networks is to give up $\mathrm{DH}$ and use individual solutions. This will make it possible to save on heat distribution losses that tend to be high in these DH network groups. If these areas still want to continue using $\mathrm{DH}$, the only possible solution is to increase the annual heat demand by adding new consumers to the network.

In conclusion, it should be noted that using HPs in rural DH networks is a solution that is worth considering. This solution can reduce the DH consumer price and is a good alternative to carbon-intensive peak boilers. It can also integrate RES into the heating sector and help to couple the heating and electricity sectors.

\section{REFERENCES}

[1] Sorknæs P., et al. The benefits of 4th generation district heating in a $100 \%$ renewable energy system. Energy 2020:213:119030. https://doi.org/10.1016/j.energy.2020.119030

[2] Trabert U., et al. Decarbonizing building stock with renewable district heating - A case study for a rural area in Germany. Proceeding of ISES Solar World Congress 2019. IEA SHC International Conference on Solar Heating and Cooling for Building Industry 2019 2020:470-481. https://doi.org/10.18086/swc.2019.11.02

[3] Polikarpova I., et al. Multi-Criteria Analysis to Select Renewable Energy Solution for District Heating System. Environmental and Climate Technologies 2019:23(3):101-109. https://doi.org/10.2478/rtuect-2019-0082

[4] Gravelsins A., et al. Solar power in district heating. P2H flexibility concept. Energy 2019:181:1023-1035. https://doi.org/10.1016/j.energy.2019.05.224

[5] Servinski M., et al. Rahvastiku paiknemine ja rahvaarv (Population location and population). Statistikaamet 2012:9. (in Estonian)

[6] Chervenkov H., et al. Degree-day climatology over central and southeast Europe for the period 1961-2018 - Evaluation in high resolution. Cybernetics and Information Technologies 2020:20:166-174. https://doi.org/10.2478/cait-2020-0070

[7] Grygierek K., et al. Energy and environmental analysis of single-family houses located in Poland. Energies 2020:13(11):2740. https://doi.org/10.3390/en13112740

[8] Kozarcanin S., et al. Impact of climate change on the cost-optimal mix of decentralised heat pump and gas boiler technologies in Europe. Energy Policy 2020:140:111386. https://doi.org/10.1016/j.enpol.2020.111386

[9] Dorotić H., et al. Impact of wind penetration in electricity markets on optimal power-to-heat capacities in a local district heating system. Renewable and Sustainable Energy Reviews 2020:132:110095. https://doi.org/10.1016/j.rser.2020.110095

[10] Bloess A. Impacts of heat sector transformation on Germany's power system through increased use of power-to-heat. Applied Energy 2019:239:560-580. https://doi.org/10.1016/i.apenergy.2019.01.101

[11] Karmellos M., Georgiou P. N., Mavrotas G. A comparison of methods for the optimal design of Distributed Energy Systems under uncertainty. Energy 2019:178:318-333. https://doi.org/10.1016/j.energy.2019.04.153

[12] Wang C., et al. Risk assessment of integrated electricity and heat system with independent energy operators based on Stackelberg game. Energy 2020:198:117349. https://doi.org/10.1016/j.energy.2020.117349

[13] Lepiksaar K., et al. Improving CHP flexibility by integrating thermal energy storage and power-to-heat technologies into the energy system. Smart Energy 2021:2:100022. https://doi.org/10.1016/j.segy.2021.100022 
[14] European Commission. COMMUNICATION FROM THE COMMISSION TO THE EUROPEAN PARLIAMENT, THE COUNCIL, THE EUROPEAN ECONOMIC AND SOCIAL COMMITTEE AND THE COMMITTEE OF THE REGIONS Powering a climate-neutral economy: An EU Strategy for Energy System Integration. Brussels: European Commission, 2020.

[15] Arabzadeh V., Pilpola S., Lund P. D. Coupling variable renewable electricity production to the heating sector through curtailment and power-to-heat strategies for accelerated emission reduction. Future Cities and Environment 2019:5(1):1-10. http://doi.org/10.5334/fce.58

[16] Bashir A. A., et al. Minimizing Wind Power Curtailment and Carbon Emissions by Power to Heat Sector Coupling A Stackelberg Game Approach. IEEE Access 2020:8:211892-211911. https://doi.org/10.1109/ACCESS.2020.3039041

[17] Rušeljuk P., et al. Factors Affecting the Improvement of District Heating. Case Studies of Estonia and Serbia. Environmental and Climate Technologies 2021:24:521-533. https://doi.org/10.2478/rtuect-2020-0121

[18] Volkova A., et al. Planning of district heating regions in Estonia. International Journal of Sustainable Energy Planning and Management 2020:27:5-15. https://doi.org/10.5278/ijsepm.3490

[19] Pieper H., et al. Assessment of a combination of three heat sources for heat pumps to supply district heating. Energy 2019:176:156-170. https://doi.org/10.1016/j.energy.2019.03.165

[20] Pieper H., et al. Modelling framework for integration of large-scale heat pumps in district heating using lowtemperature heat sources: A case study of Tallinn, Estonia. International Journal of Sustainable Energy Planning and Management 2019:20:67-86. https://doi.org/10.5278/ijsepm.2019.20.6

[21] Volkova A., et al. Small low-temperature district heating network development prospects. Energy 2019:178:714-722. https://doi.org/10.1016/j.energy.2019.04.083

[22] Terreros O., et al. Electricity market options for heat pumps in rural district heating networks in Austria. Energy 2020:196:116875. https://doi.org/10.1016/j.energy.2019.116875

[23] Augutis J., et al. Analysis of energy security level in the Baltic States based on indicator approach. Energy 2020:199:117427. https://doi.org/10.1016/j.energy.2020.117427

[24] Litgrid, AST, Elering. Review of RES perspective in Baltic countries till 2030. 2015.

[25] Rummel L. Kaarepere küla ja Luua küla soojusmajanduse arengukava aastateks 2017-2027 (Approval of the heat management development plan of Palamuse small town, Kaarepere village and Luua village for 2017-2027.). Palamuse: Palamuse Vallavolikogu, 2017. (in Estonian)

[26] Rummel L. Mäetaguse valla Mäetaguse aleviku ja Kiikla küla soojusmajanduse arengukava aastateks 2017-2030 (Mäetaguse rural municipality Mäetaguse small town and Kiikla village heat management development plan for 20172030). Mäetaguse: Mäetaguse Vallavolikogu, 2017. (in Estonian)

[27] Sweco, Port of Tallinn. Cruise Terminal of Old City Harbour. Sustainable energetic solutions for cruise terminal buildings in Northern Climate. Tallin: Sweco, 2017.

[28] Woolley K. E., et al. Effectiveness of interventions to reduce household air pollution from solid biomass fuels and improve maternal and child health outcomes in low- and middle-income countries: a systematic review protocol. Systematic Reviews 2021:10(33):1-7. https://doi.org/10.1186/s13643-021-01590-z

[29] Cheng W., et al. Mitigation of ultrafine particulate matter emission from agricultural biomass pellet combustion by the additive of phosphoric acid modified kaolin. Renewable Energy 2021:172:177-187.

https://doi.org/10.1016/j.renene.2021.03.041

[30] Kažimírová V., Opáth R. Biomass combustion emissions. Research in Agricultural Engineering 2016:62:S61-S65. https://doi.org/10.17221/69/2015-RAE

[31] Directive (EU) 2015/2193 of the European Parliament and of the Council of 25 November 2015 on the limitation of emissions of certain pollutants into the air from medium combustion plants. Official Journal of the European Union 2015:L 313/1.

[32] European Parliament and Council. DIRECTIVE (EU) 2016/2284 OF THE EUROPEAN PARLIAMENT AND OF THE COUNCIL of 14 December 2016 on on the reduction of national emissions of certain atmospheric pollutants, amending Directive 2003/35/EC and repealing Directive 2001/81/EC. Official Journal of the European Union 2016:L $344: 1$.

[33] European Commission. Operational Programme for Cohesion Policy Funding 2014-2020. Estonia 2014 [Online]. [Accessed 15.03.2021]. Available: https:/ec.europa.eu/regional_policy/en/atlas/programmes/20142020/estonia/2014ee16m3op001

[34] European Commission. 2050 long-term strategy [Online]. [Accessed 15.03.2021]. Availabe: https://ec.europa.eu/clima/policies/strategies/2050_en

[35] Eesti Konkurentsiamet. Kooskõlastatud soojuse piirhinnad (Coordinated marginal heat prices) [Online]. [Accessed 15.03.2021]. Available: https:/www.konkurentsiamet.ee/et/vesi-soojus/soojus/kooskolastatud-soojuse-piirhinnad_(in Estonian)

[36] National Weather Service. Observation data [Online]. [Accessed 14.03.2021]. Available: https://www.ilmateenistus.ee/ilm/ilmavaatlused/vaatlusandmed/ (in Estonian)

[37] Konkurentsiamet. Soojuse piirhinna kooskõlastamise põhimõtted (03.05.2013 käskkiri nr 1.1-2/13-012) (Principles of approval of the maximum heat price (Directive No. 1.1-2 / 13-012 of 03.05.2013.). Tallin: Estonian Competiton Authority, 2020. (in Estonian) 
[38] Keskkonnaministeerium. Keskkonnatasude Raamkava Aastateks 2016-2025 (Environmental Charges Framework Plan for 2016-2025.). Tallin: Ministry of the Environment, 2014. (in Estonian)

[39] PHS Engineers. Biomass (Wood-Pellet) Boiler VS Conventional Gas Boiler - Pros \& Cons [Online]. [Accessed 15.03.2021]. Available: https://phsengineersltd.co.uk/biomass-wood-pellet-boiler/

[40] Danish Energy Agency. Drejebog til store varmepumpeprojekter i fjernvarmesystemet (Guide for large-scale heat pump projects in district heating systems.). Kolding: DEA, 2017.

[41] Knobloch F., et al. A technical analysis of FTT:Heat - A simulation model for technological change in the residential heating sector. Technical Study on the Macroeconomics of Energy and Climate Policies. Brussels: European Commission, 2017.

[42] Environmental Investment Center. Funded applications [Online]. [Accessed 08.01.2021]. Available: https://www.kik.ee/et/rahastatud-projektid (in Estonian)

[43] Pieper H., et al. Allocation of investment costs for large-scale heat pumps supplying district heating. Energy Procedia 2018:147:358-367. https://doi.org/10.1016/j.egypro.2018.07.104

[44] Majandus- ja kommunikatsiooni Ministeerium, Vaks R. Open public discussion about European Union support on topics 'Greener Estonia' in 'Energy efficient consumption'. 2020 